\title{
PENGARUH SOSIAL EKONOMI ORANG TUA TERHADAP INDEKS PRESTASI MAHASISWA JURUSAN PENDIDIKAN EKONOMI UNIVERSITAS NEGERI SURABAYA
}

\author{
Fathur Rahman Khoirurroziqin \\ S1 Pendidikan Ekonomi Fakultas Ekonomi Universitas Negeri Surabaya \\ fathurrahmankh@gmail.com \\ Mohamad Arief Rafsanjani \\ S1 Pendidikan Ekonomi Fakultas Ekonomi Universitas Negeri Surabaya \\ mohamadrafsanjani@unesa.ac.id
}

\begin{abstract}
Abstrak
Tujuan dari Riset ini untuk mengetahui bagaimana sosial ekonomi orang tua Jurusan Pendidikan Ekonomi Universitas Negeri Surabaya dan apakah ada pengaruh sosial ekonomi orang tua pada indeks prestasi mahasiswa. Penelitian ini dilakukan di departemen pendidikan ekonomi tepatnya untuk siswa dari S1 kelas 1 dan kelas B. Program Studi Pendidikan Ekonomi. Penelitian ini dimulai dari bulan Maret hingga April 2020. Dengan menerapkan acak sederhana pada teknik probability sampling. Instrumen dalam penelitian ini menggunakan daftar pertanyaan sebagai media penelitian untuk menjelaskan status sosial ekonomi keluarga dan untuk mendapatkan indeks prestasi siswa dengan mendokumentasikan. Dengan total 82 siswa diambil sampel dari 68 siswa yang terlibat. Menerapkan metode regresi Linear sederhana yang diterapkan dalam pemrosesan data. Hal ini dibuktikan dengan uji-t $<\mathrm{t}$ tabel maka untuk variabel $\mathrm{X}$ (status sosial ekonomi orang tua) <t tabel. Dan uji F dihitung <nilai F tabel. Data menunjukkan Rsquare 2,2\%, ini berarti pengaruh kondisi status sosial ekonomi terhadap indeks prestasi siswa sangat rendah dan 97,8\% yang mempengaruhi indeks prestasi siswa dapat dijelaskan dengan variabel di luar penelitian ini. dapat disimpulkan bahwa temuan penelitian ini menunjukkan bahwa variabel status sosial ekonomi orang tua tidak mempengaruhi indeks prestasi belajar siswa.
\end{abstract}

Kata Kunci: Indeks Prestasi, Status sosial ekonomi.

\begin{abstract}
The purpose of this research is to find out how the socioeconomic parents of the Department of Economic Education, Surabaya State University and whether there is a socioeconomic influence of parents on the student achievement index. This research was conducted in the department of economic education precisely for students from S1 class 1 and class B. Economic Education Study Program. This research starts from March to April 2020. By applying simple random sampling on probability sampling techniques. The instrument in this study used a questionnaire as a research medium to explain the socioeconomic status of the family and to obtain an index of student achievement by documenting. A total of 82 students were sampled from the 68 students involved. Implement a simple Linear regression method that is applied in data processing. This is evidenced by the t-test $<\mathrm{t}$ table then for variable $\mathrm{X}$ (socioeconomic status of parents) $<\mathrm{t}$ table. And the $\mathrm{F}$ test is calculated $<\mathrm{F}$ table value. The data shows Rsquare $2.2 \%$, this means that the influence of socioeconomic status conditions on student achievement index is very low and $97.8 \%$ which affects student achievement index can be explained by variables outside this study. it can be concluded that the findings of this study indicate that the variable socioeconomic status of parents does not affect student achievement index..
\end{abstract}

Keywords: GPA, socioeconomic status.

\section{PENDAHULUAN}

Pendidikan harus diselenggarakan baik secara kualitas maupun kuantitas. Kedua hal ini tidak boleh berat sebelah, baik secara kualitas dan kuantitas harus seimbang. Hubungan yang ada kaitanya dengan kecerdasan dan kemampuan adalah kualitas. Sedangan kuantitas berhubungan erat dengan angka dan jumlah (Rahmayanti, 2016:207). Hal tersebut dapat dilihat dari indeks prestasi belajar mahasiswa setelah memperoleh kegiatan belajar melalui perkuliahan. Perubahan tingkah laku serta pola pikir setiap orang dipengaruhi oleh kegiatan orang tersebut dalam berinteraksi dengan lingkunganya. Interaksi tersebut adalah belajar. Proses belajar tersebut tidak mengenal batas usia maupun seberapa lama kegiatan itu dilakukan. Dengan begitu belajar merupakan faktor penentu keberhasilan seseorang dalam mengejar masa depan. 
Pendidikan dapat berlangsung secara formal maupun informal. Lingkungan pendidikan adalah salah satu bentuk pertama untuk menunjang mahasiswa untuk berinteraksi dengan berbagai lingkungan sekitarnya. Lingkungan utama tersebut digolongkan menjadi tiga hal yaitu kondisi keluarga, masyarakat, dan sekolah lebih dikenal sebagai tri pusat pendidikan (Munib (2012:76).

Pendidikan dalam keluarga merupakan pendidikan paling utama dalam pembentukan karakter anak. Keluarga merupakan Sosialisasi pertama bagi anak untuk mengenali lingkungan sosial, budaya dan juga mengenal anggota keluarga (Narwoko2011:92).

Komunikasi dalam keluarga menjadi hal yang sangat vital karena hubungan yang dijalin oleh orangtua dan anak akan mempengaruhi keterampilan serta pencapaian peserta didik dalam belajar. Arahan serta bimbingan yang inten akan dapat membimbing anak dalam proses pembelajaran yang baik.

Tidak hanya Interaksi yang baik dengan orangtua, sosial ekonomi orang tua juga memiliki peran untuk menentukan pencapaian keterampilan anak terutama pencapaian prestasi. Perubahan individu yang diakibatkan dari kesan-kesan yang dihasilkan dari aktifitas belajar adalah penggambaran dari prestasi belajar. Banyak hal yang dapat mempengaruhi dalam proses pencapaian anak dalam mendapatkan prestasi belajar salah satunya fakor intern dan ekstern. Faktor Intern meliputu minat, bakat, dan tingkat intelegensi. Faktor ekstern meliputi fasilitas belajar, kondisi lingkungan, status ekonomi dan pengajaran. Dua faktor tersebut harus saling berkesinambungan agar prestasi belajar tercapai secara optimal. Pencapaian prestasi anak dapat dipengaruhi dari tingkat pendidikan orang tua, status sosial ekonomi, rumah hunian, interaksi didalam lingkungan keluarga serta bimbingan (Djaali (2014:9).

Fasilitas pembelajaran saat ini sangat jauh berbeda dengan zaman dulu. Zaman sekarang mengalami era globalisasi, ditunjang dari segi kecanggihan teknologi yang sudah menjadi konsumsi umum bagi setiap orang.

Dalam wawancara yang dilakukan pada mahasiswa pendidikan ekonomi 2017 lewat jarak jauh oleh peneliti ditemukan bahwa status sosial ekonomi yang dimiliki oleh mahasiswa cnderung berbeda beda. Mahasiswa tersebut tergolong dalam keluarga yang berstatus ekonomi tinggi bahkan tidak sedikit juga yang berada dalam status ekonomi yang tergolong rendah. Karena keberagaman tingkat sosial ekonomi tersebut dapat berpengaruh dalam proses mahasiswa untuk mendapatkan hasil belajar. Keadaan sosial ekonomi keluarga sangat berpengaruh kepada perkembangan anak. Dengan tingkat ekonomi yang memadai serta lingkungan material yang dijumpai anak lebih luas pada lingkungan keluarga maka ia mendapatkan ruang gerak lebih banyak untuk mengasah keterampilan serta kemampuan yang tidak dapat ia kembangkan jika tidak ada prasarana (Gerungan (2004:196)).

Jenjang pendidikan terakhir yang dimiliki orangtua mahasiswa juga bermacam- macam. Mulai dari tamatan SD. SMP hanya sampai bangku SMA bahkan ada pula yang melanjutkan pendidkan strata 1 . Hal tersebut menjadi salah satu faktor yang mempengaruhi seberapa besar tingkat pendapatan gaji orangtua dalam keluarga.

Berdasar pada hal tersebut masyarakat cenderung beranggapan jika keberhasilan mahasiswa ditentukan oleh latar belakang sosial ekonomi keluarga seperti pendidkan dan pendapatan orangtua.

Pendapatan orangtua tentu berpengaruh dalam pemenuhan fasilitas belajar anak. Kebutuhan fasilitas serta kelengkapan anak dalam belajar. Seperti halnya buku, alat komunikasi serta barang- barang lain yang dibutuhkan untuk menunjang dalam kegiatan belajar anak. Berdasarkan penuturan salah seorang mahasiswa tidak sedikit dari mereka untuk berangkat ke kampus serta ke perpustakaan guna mencari buku dan literature yang menunjang belajar mereka dengan berjalan kaki ada pula dari mereka di berikan fasilitas transportasi dari orangtua. Hal tersebut tentunya sangat mempengaruhi proses pencapaian belajar anak. Tingkat pendidikan, kekayaan serta penghasilan orang tua merupakan indikator status sosial ekonomi (Taneko(2000:131)).

Hasil belajar mahasiswa menunjukan hasil yang cukup memuaskan. Ini terlihat dari keterangan mahasiswa sendiri yang mengatakan pencapaian hasil belajar mereka pada tingkat diatas standar yang ditentukan. Tetapi ada pula dari mereka yang memiliki hasil belajar yang kurang memuaskan.

Status sosial ekonomi orangtua cenderung berpengaruh dalam proses perolehan hasil belajar anak. Wirawan (205), dalam penelitianya menyatakan status sosial ekonomi orang tua mempengaruhi siswa untuk mencapai prestasi belajar ekonomi. Riset lain yang dilakukan oleh Chotimah, Ani, \& Widodo (2017) menunjukan pencapaian prestasi dipengaruhi oleh status sosial ekonomi orangtuanya

Riset ini berupaya untuk menggali faktor yang berdampak bagi pencapaian indeks prestasi mahasiswa.

\section{METODE}

Pendekatan yang digunakan pada riset ini yaitu deskriptif kuantitatif asosiatif. Yaitu menguji ada tidaknya kaitan antara variabel satu dengan variabel lainya. Gambaran rancangan riset ini sebagai berikut 


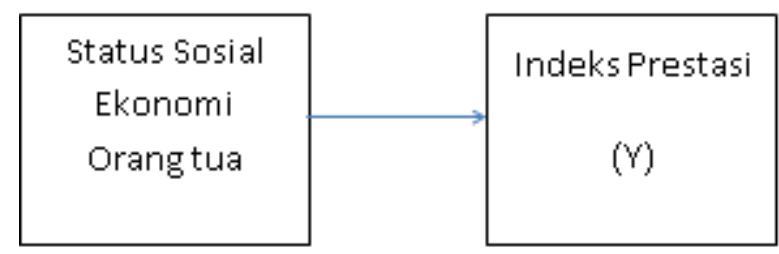

Gambar 1 : Rancangan Riset

Riset ini dilakukan di Fakultas Ekonomi Universitas Surabaya dengan mengambil sampel dari prodi S1 Pendiadikan Ekonomi Jurusan S1 Pendidikan ekonomi angkatan 2017 kelas A dan B. berdasarkan data dari TU jurusan pendidikan ekonomi terdapat 82 mahasiswa dari kelas A dan B. sampel yang dilibatkan dalam riset ini. menggunakan 68 mahasiswa yang diambil secara random.

Pengumpulan data harus dilakukan dengan sistematis, terarah, dan sesui dengan masalah penelitian.

Teknik pengumpulan data yang digunakan dalam penelitian ini adalah Metode Angket (kuisioner) dan Metode Dokumentasi.

Angket diberikan untuk mengetahui kondisi status sosial ekonomi orangtua. Data dokumentasi ini diperlukan untuk mengetahui jumlah mahasiswa dan nilai IPK Prodi S1 Pendidikan Ekonomi Jurusan Pendidikan Ekonomi Universitas Negeri Surabaya.

Untuk variabel bebasnya adalah status sosial ekonomi dilihat dari 3 item indicator yaitu tingkat pendapatan, kekayaan atau fasilitas dan pendapatan ekonomi. Instrument untuk mengukur tingkat status sosial ekonomi ini dengan daftar pertanyaan dengan memilih pilihan alternative yang disediakan oleh peneliti. Semua pilihan tersebut menggunakan skala interval dari $1=\mathrm{D}$ sampai $4=$ A.

Variabel terikatnya adalah Indeks Prestasi Mahasiswa. Instrument yang digunakan untuk mengungkap variabel prestasi belajar menggunakan metode dokumentasi dengan mencatat data-data nilai IP Mahaiswa melalui dokumentasi di TU Jurusan dan di dapat dari penyebaran angket.

Teknik analisis data dalam riset ini menggunakan analisis deskriptif dan regresi linier sederhana dengan bantuan program spss V26. Tujuan riset dilakukan untuk menganalisis status sosial ekonomi dan indeks prestasi mahasiswa berpengaruh atau tidak berpengaruh.

\section{HASIL DAN PEMBAHASAN}

Berikut ini merupakan hasil analisis data menggunakan spss V26. Hasil uji instrument dengan 68 responden dengan 20 butir pertanyaan. Uji angket dinyatakan valid apabila memenuhi syarat validitas yang berlaku. Syarat ini dapat dilihat $\mathrm{R}$ hitung $>\mathrm{r}$ table dengan signifikan $5 \%$ atau $r$ hitung lebih dari $>0.254$. jika syarat tersebut telah terpenuhi maka item2 dari angket dinyatakan sah atau valid.
Tabel 1 Uji Validasi

\begin{tabular}{|r|r|r|l|}
\hline \multicolumn{1}{|l|}{ No } & \multicolumn{1}{l|}{ Rhitung } & \multicolumn{1}{l|}{ Rtabel } & Ket \\
\hline 1 & $.694^{* *}$ & 0.254 & Valid \\
\hline 2 & $.627^{* *}$ & 0.254 & Valid \\
\hline 3 & $.504^{* *}$ & 0.254 & Valid \\
\hline 4 & $.700^{* *}$ & 0.254 & Valid \\
\hline 5 & $.267^{*}$ & 0.254 & Valid \\
\hline 6 & $.310^{* *}$ & 0.254 & Valid \\
\hline 7 & $.620^{* *}$ & 0.254 & Valid \\
\hline 8 & $.648^{* *}$ & 0.254 & Valid \\
\hline 9 & $.536^{* *}$ & 0.254 & Valid \\
\hline 10 & $.740^{* *}$ & 0.254 & Valid \\
\hline 11 & $.774^{* *}$ & 0.254 & Valid \\
\hline 12 & $.469^{* *}$ & 0.254 & Valid \\
\hline 13 & $.626^{* *}$ & 0.254 & Valid \\
\hline 14 & $.677^{* *}$ & 0.254 & Valid \\
\hline 15 & $.394^{* *}$ & 0.254 & Valid \\
\hline 16 & $.701^{* *}$ & 0.254 & Valid \\
\hline 17 & $.256^{*}$ & 0.254 & Valid \\
\hline 18 & $.563^{* *}$ & 0.254 & Valid \\
\hline 19 & $.269^{*}$ & 0.254 & Valid \\
\hline 20 & $.725^{* *}$ & 0.254 & Valid \\
\hline
\end{tabular}

(Sumber : temuan data peneliti)

Nilai Rtabel per item pertanyaan menunjukan nilai antara .256* sampai .774**. Berdasarakan pada pernyataan tersebut maka dapat simpulkan Rhitung dari semua item lebih besar dari Rtable maka keseluruhan item pertanyaan dinyatakan lolos uji validitas.

Setelah uji validitas dilakukan selanjutnya diadakan uji reliabilitas. Uji realibilitas ini dilakukan dengan syarat Cronbach's Alpha $>$ Rtable dengan taraf signifikan 5\% atau Cronbach alpha > 0.254 apabila ketentuan sudah memenuhi maka pertanyaan dinyatakan reliabilitas.

Cronbach's Alpha dari semua item menunjukan 0.878. yang berarti lebih besar dari Rtabel 0,878 >0,254. maka semua item pertanyaan realibilitas dan layak untuk melakukan pengumpulan data.

Hasil analisis deskriptif yang telah dilakukan peneliti menemukan bahwa

Tabel 2. Distribusi Frekuensi Prosentase Status Sosial Ekonomi Orang Tua 


\begin{tabular}{|c|c|c|c|}
\hline Interval & Kategori & Responden & Prosentase \\
\hline $53-63$ & Tinggi & 17 & $25 \%$ \\
\hline $42-52$ & Sedang & 28 & $41 \%$ \\
\hline $31-41$ & Rendah & 23 & $34 \%$ \\
\hline & & 68 & $100 \%$ \\
\hline
\end{tabular}

(Sumber : temuan data peneliti)

Menurut tabel data diatas menunjukan bahwa tingkat tinggi, sedang, dan rendah sebesar $25 \%, 41 \%$, dan $34 \%$. Berdasarkan hal tersebut bisa ditarik kesimpulan bahwa status sosial ekonomi orang tua mahasiswa terhadap indeks prestasi tergolong sedang sebesar $41 \%$.

Tabel 3. Distribusi Frekuensi Prosentase Indeks Prestasi Mahasisw Angkatan 2017

\begin{tabular}{|c|c|c|c|}
\hline IPK & Kriteria & Responden & Prosentase \\
\hline $\begin{array}{c}2.70- \\
3.00\end{array}$ & Memuaskan & 9 & $13 \%$ \\
\hline $\begin{array}{c}3.01- \\
3.50\end{array}$ & $\begin{array}{c}\text { Sangat } \\
\text { Memuaskan }\end{array}$ & 44 & $70 \%$ \\
\hline $\begin{array}{c}3.51- \\
4.00\end{array}$ & Pujian & 15 & $22 \%$ \\
\hline Jumlah & & 68 & $100 \%$ \\
\hline
\end{tabular}

(Sumber : temuan data peneliti)

Dari data tabel diatas dapat disimpulkan bahwa Indeks Prestasi mahasiswa yang memuaskan sebesar $13 \%$, sangat memuaskan sebesar $70 \%$, dan pujian sebesar $22 \%$. Indeks Prestasi mahasiswa tergolong dalam kategori sangat memuaskan yaitu $70 \%$.

Setelah melakukan analisis pendahuluan kemudian dilanjutkan dengan analisis lanjutan yaitu analisis linier regresi sederhana menggunakan aplikasi SPSS ver 26 untuk mengetahui apakah ada pengaruh antara variabel bebas terhadap variabel terikat.

Tabel 4. Model Summary

\begin{tabular}{|c|}
\hline Model Summary \\
\hline R Square \\
\hline .022 \\
\hline
\end{tabular}

(Sumber : temuan data peneliti)
Berdasarkan table diatas koefisien determinasi dapat diketahui apabila dihitung dengan mengalikan Rsquare dengan $100 \%$. Maka :

Nilai R square dalam table tersebut adalah 0.022 . 0.022 adalah koefisien determinasi. jadi $0.022 \times 100 \%=$ $2,2 \%$ variabel bebas dapat menjelaskan variabel terikat sementara sisanya dapat dideskripsikan oleh variabel lain diluar model regresi pada riset ini.

Tabel 5. Tabel Anova

\begin{tabular}{|c|c|}
\hline \multicolumn{2}{|c|}{ ANOVA } \\
\hline Df & F \\
\hline 1 & 1.472 \\
\hline
\end{tabular}

(Sumber : temuan data peneliti)

Maka pertama kita merumuskan hipotesis yaitu Ho : Status sosial ekonomi orang tua tidak berpengaruh terhadap indeks prestasi mahasiswa dan Ha : Status sosial ekonomi orang tua berpengaruh terhadap indeks prestasi mahasiswa Setelah menuruskan hipotesis maka mencari Ftabel dengan nilai signifikan $=0.05$ dengan mencari Degree of freedom dengan cara DF1 = Total variabel ( bebas+terikat ) -1 maka $2-1=1$ dan DF2 = Total responden - Jumlah variabel $=68-2=66$. Dengan melihat Tabel $\mathrm{F}$ dengan data diatas maka $\mathrm{F}$ table $=3.99$. setelah Ftabel ditemukan maka hipotesisnya dapat ditentukan dengan krieria : apabila nilai Fhitung > Ftabel maka Ho ditolak dan $\mathrm{Ha}$ diterima dan apabila nilai Fhitung < Ftabel maka Ho diterima dan Ha ditolak. Setelah temuan hasil diatas maka Nilai Fhitung dari table ANOVA diatas $>$ Nilai Ftabel $(1.472<3.9)$ kesimpulanya hipotesis Status sosial ekonomi orang tua tidak berpengaruh terhadap indeks prestasi mahasiswa.

Tabel 6. Coeffisients

\begin{tabular}{|c|c|}
\hline \multicolumn{2}{|c|}{ Coefficients } \\
\hline \multirow{2}{*}{ Model } & $\begin{array}{c}\text { Unstandardized } \\
\text { Coeffisients }\end{array}$ \\
\cline { 2 - 2 } & $\mathrm{B}$ \\
\hline Constant & 3.530 \\
\hline $\mathrm{X}$ & -.006 \\
\hline
\end{tabular}

(Sumber : temuan data peneliti 
Untuk mengetahui angka konstan serta uji hipotesis terhadap variabel bebas dan terikat maka dilakukan menggunakan rumus regresi linier sederhana.

Persamaan regresinya sebagai berikut:

$Y=a+B x$

Keterangan :

$\mathrm{Y}=$ Indeks Prestasi

$\mathrm{X}=$ Status Sosial Ekonomi

$\mathrm{a}=$ Angka Konstatn dari Unstandardized Coefficients

$\mathrm{B}=$ Angka Koefisien regresi

( Sugiyono,2014 : 270 )

Maka persamaan yang diperoleh adalah:

$$
\mathrm{Y}=3.530+(-0.006) \mathrm{X}
$$

Kesimpulannya adalah Konstanta 3,530 menyatakan apabila status sosial ekonomi konstan, maka indeks prestasi mahasiswa sebesar 3,530.

Koefesien regresi variabel terikat ( status sosial ekonomi orang tua ) sebesar -0.006 menyatakan bahwa apabila ditingkatkan 1 point akan berpengaruh negative 0,006 terhadap indeks prestasi mahasiswa. Maka variabel terikat telah memegang sumbangan -0.006 kepada indeks prestasi mahasiswa.

Karena nilai koefiien bernilai minus, maka dapat dikatakan_variabel bebas berefek negative terhadap indeks prestasi. Sehingga persamaan regresinya adalah $\mathrm{Y}$ $=3.530-0.006 \mathrm{X}$

Setelah itu kita melakukan Uji T untuk menguji signifikan konstanta serta variabel status sosial ekonomi dipakai untuuk predictor variabel indeks prestasi mahasiswa.

Langkah pertama merumuskan hipotesis yaitu : Ho = Koefisien regresi tidak signifikan dan $\mathrm{Ha}=$ Koefisien regresi signifikan. Setelah itu menentukn Ttable dengan acuan nilai $\alpha$ ( Taraf signifikan) $/ 2=0.05 / 2=0.025$ dan mencari degree of Freedom ( DF ) dengan rumus jumlah responden - 2( jumlah variabel) maka hasilnya menjadi 68-2 = 66. Jadi nilai Ttable yang di dapat menunjukan pada angka 1,996 .

Setelah Ttable ditemukan maka dapat menentukan hipotesis melalui kriteria sebagai berikut: Apabila nilai Thitung > Ttabel maka Ho ditolak dan Ha diterima atau apabila nilai Thitung < Ttabel maka Ho diterima dan $\mathrm{Ha}$ ditolak.

Setelah temuan data karena nilai Thitung < nilai Ttabel maka $(-1.213<1,996)$ maka hipotesis yang dapat diambil yaitu koefisien regresi terbukti tidak signifikan.

Dengan demikian pernyataan diatas menunjukan : "Kondisi status sosial ekonomi orang tua tidak berpengaruh terhadap indeks prestasi mahasiswa jurusan pendidikan ekonomi di universitas negeri Surabaya".

\section{PEMBAHASAN}

Dengan status sosial ekonomi orang tua yang baik akan dapat memenuhi berbagai kebutuhan anak dalam belajarnya. Fasilitas belajar anak menjadi salah satu faktor penunjang pencapaian prestasii belajar siswa. Hal tersebut di dukung oleh pernyataan Djaali (2014:09) tingkat prestasi orangtua, taraf ekonomi keluarga, presentase interaksi kluarga, rumah kediaman, komunikasi, serta arahan konseling yang diberikan keluarga terhadap anak dapat mendorong perolehan dalam akademik siswa.

Hasil analisisi data yang telah ditemukan menunjukan status sosial ekonomi orang tua tidak berpengaruh terhadap indeks prestasi mahasiswa terlihat dari uji $\mathrm{F}$ dari table ANOVA yang menunjukan Fhitung lebih kecil dari Ftabel (1.472 < 3.99). Hal ini juga diperkuat dengan dilakukanya uji T yang menunjukan nilai Thitung $1.213<$ nilai Ttabel 1,996 ) dapat dikatakan koefisien regresi tidak signifikan.

Temuan riset ini menunjukan bahwa rata-rata status sosial ekonomi orangtua terlihat pada tingkat sedang berdasarkan dari pendidikan, kekayaan dan fasilitas serta pendapatan orang tua. Meskipun begitu pencapaian indeks prestasi cukup tinggi. Dapat disimpulkan variabel bebas yaitu status sosial ekonomi tidak berpengaruh terhadap variabel terikat. karena nilai angka koefisien determinasi menunjukan nilai $\mathrm{R}$ square sangat lemah sebesar 2,2\% yang berarti angka tersebut mewakili status sosial ekonomi yang menjelaskan indek prestasi mahasiswa sementara sisanya di terangkan oleh variabel diluar riset ini..

Hasil riset tersebut tidak relevan dengan riset sebelumnya yang menunjukan apabila semakin baik taraf sosial keluarga akan semakin baik pula prestasi anak yang di dapatkan (Suminah 2016). Riset lain yang tidak relevan menyatakan status sosial ekonomi orang tua memiliki peran dalam pencapaian prestasi anak melali pemenuhan berbagai kebutuhan belajar anak (Peterson 2000). Begitu pula dengan riset lain tentang "The Relationship Between Socio-Economic Status and Learning Achievement of Student secondary Level'(Akhtar dan Hamid : 2011) menunjukan bahwa status sosial ekonomi berpengaruh signifikan yang bersifat positif terhadap prestasi belajar.

Hal ini mungkin dikarenakan variabel yang digunakan memiliki pengaruh yang berbeda sehingga didapatkan hasil yang menunjukan bahwa indeks prestasi tidak dipengaruhi oleh variabel bebasnya yaitu status sosial ekonomi orangtua. Perbedaan indicator dalam variabel juga memiliki nilai yang bervariasi yang dapat mempengaruhi hasil riset. 


\section{PENUTUP}

\section{Simpulan}

Riset ini menunjukkan keadaan status sosial ekonomi orang tua terhadap indeks prestasi mahasiswa rata-rata terletak pada taraf predikat sedang sedangkan sisanya rendah dan tinggi. Status sosial ekonomi orang tua tidak berpengaruh pengaruh signifikan terhadap Indeks prestasi mahasiswa meskipun data yang ditemukan menunjukan angka koefisien regresi bernilai negative terhadap variabel terikatnya. Analisis regresi linier sederhana menunjukan pengaruh variabel $\mathrm{X}$ terhadap variabel $\mathrm{Y}$ sangat rendah dan pengaruh lainya di pengaruhi oleh faktor berbeda diluar riset ini.

Riset dilakukan dengan metode kuantitatif sehingga belum dapat mengungkap secara detail kondisi status sosial ekonomi orang tua karena sangat memungkinkan indikator yang berbeda-beda bisa menunjukan hasil yang lebih detai

\section{Saran}

Maka peneliti menyarankan kepada peneliti selanjutnya untuk menguji kembali hasil riset ini dengan menggunakan indikator yang berbeda guna mengungkap secara lebih detail tentang status social ekonomi orang tua yang mempengaruhi indeks prestasi mahasiswa.

\section{DAFTAR PUSTAKA}

Akthar, Z., \& Hamid Khan Niazi, (2011). THE RELATIONSHIP BETWEEN SOCIO-ECONOMIC STATUS AND LEARNING ACHIEVEMENT OF STUDENTS A SECONDARY LEVEL. International Journal of Academic Research, 3 (2), 956-962

Chotimah, N.L., Hesty M.A., \& Joko Widodo, (2017). Pengaruh Status Sosial Ekonomi Orangtua terhadap Prestasi Belajar Siswa. Jurnal Pendidikan Ekonomi, 11(1), 75-80

Djaali, (2014). Psikologi Pendidikan. Jakarta: Bumi Aksara

Gerungan, (2004). Psikologi Sosial. Bandung: Refika Aditama

Munib, Ahmad. (2012). Pengantar Ilmu Pendidiksn. Semarang: UPT UNNES Press

Narwoko, (2011). Sosiologi Teks Pengantar dan Terapan. Surabaya: Kencana

Peterson, (2000). Cross-Cultural Studies on Moral Development Using The Defining. Journal of International Personality and Organization. Juni 2000, 24-138

Rahmayanti, V. (2016). PENGARUH MINAT BELAJAR SISWA DAN PERSEPSI ATAS UPAYA GURU DALAM MEMOTIVASI BELAJAR SISWA
TERHADAP PRESTASI BELAJAR BAHASA INDONESIA SISWA SMP DI DEPOK. Jurnal SAP, 1(2), 206-216

Sugiyono, (2014). Metode Penelitian Pendidikan ( Pendidikan Kuantitatif, Kualitatif, dan R\&D. Bandung: Alfabeta

Suminah, (2016). Pengaruh Status Sosial Ekonomi Orang tua terhadap Hasil Belajar PKN Siswa Kelas V SDN segugus Kresna Kecamatan Semarang Barat. Skripsi. FIP. Pendidikan Guru Sekolah Dasar. Universitas Negeri Semarang. Semarang

Taneko, Soleman B. (2000). Struktur dan Proses Sosial Suatu Pengantar Sosiologi Pembagunan. Jakarta: PT Raja Grafindo Persada

Wirawan, Yahya Reka. (2017). Pengaruh Status Sosial ekonomi Orang tua terhadap Prestasi belajar Ekonomi dan Perilaku Konsumsi Siswa. Jurnal Ilmiah Ekonomi dan Pembelajaranya, 3(1),549-617. 